\title{
The influence of conservation tillage methods on soil water regimes in semi-arid southern Zimbabwe
}

\author{
W. Mupangwa ${ }^{\mathrm{a}, \mathrm{b}, *}, \mathrm{~S}$. Twomlow ${ }^{\mathrm{a}}, \mathrm{S}$. Walker ${ }^{\mathrm{b}}$ \\ a ICRISAT Bulawayo, Matopos Research Station, P O Box 776, Bulawayo, Zimbabwe \\ ${ }^{\mathrm{b}}$ Department Soil, Crop and Climate Sciences, University of Free State, Bloemfontein, South Africa
}

A R T I C L E I N F O

Available online 10 July 2008

\section{Keywords:}

Double ploughing

Planting basins

Ripping

Soil water

\begin{abstract}
A B S T R A C T
Planting basins and ripper tillage practices are major components of the recently introduced conservation agriculture package that is being extensively promoted for smallholder farming in Zimbabwe. Besides preparing land for crop planting, these two technologies also help in collecting and using rainwater more efficiently in semi-arid areas. The basin tillage is being targeted for households with limited or no access to draught animals while ripping is meant for smallholder farmers with some draught animal power. Trials were established at four farms in Gwanda and Insiza in southern Zimbabwe to determine soil water contributions and runoff water losses from plots under four different tillage treatments. The tillage treatments were hand-dug planting basins, ripping, conventional spring and double ploughing using animal-drawn implements. The initial intention was to measure soil water changes and runoff losses from cropped plots under the four tillage practices. However, due to total crop failure, only soil water and runoff were measured from bare plots between December 2006 and April 2007. Runoff losses were highest under conventional ploughing. Planting basins retained most of the rainwater that fell during each rainfall event. The amount of rainfall received at each farm significantly influenced the volume of runoff water measured. Runoff water volume increased with increase in the amount of rainfall received at each farm. Soil water content was consistently higher under basin tillage than the other three tillage treatments. Significant differences in soil water content were observed across the farms according to soil types from sand to loamy sand. The basin tillage method gives a better control of water losses from the farmers' fields. The planting basin tillage method has a greater potential for providing soil water to crops than ripper, double and single conventional ploughing practices.
\end{abstract}

(c) 2008 Elsevier Ltd. All rights reserved.

\section{Introduction}

Smallholder agriculture in semi-arid areas is hampered by biophysical and climatic constraints among others. The predominant chemical and physical challenges with soils in smallholder farming areas of Zimbabwe include low organic matter, low $\mathrm{pH}$ and poor structure (Nyamangara and Mpofu, 1996; Twomlow et al., 2006). Marginal lands once used for grazing have been opened for cropping and this further increases the erosion risk of the poor structured soils (Whitlow, 1988). The spatial distribution of water in the soil is further restricted by the presence of a hard plough pan. In the wetter Agroecological regions II and III of Zimbabwe, Tsimba et al. (1999) observed a plough pan at $10-15 \mathrm{~cm}$ depth within the soil profile across 23 farms. Poor land management which is rampant in the semi-arid smallholder farming sector continues to threaten agricultural productivity in Zimbabwe.

\footnotetext{
* Corresponding author.

E-mail address: w.mupangwa@cgiar.org (W. Mupangwa).
}

Climatic challenges especially changes in rainfall patterns pose a major threat on household food security. In semi-arid areas rainfall is low, erratic and highly variable both in space and time (Rockstrom et al., 2002). The long-term annual average rainfall in southern Zimbabwe is $590 \mathrm{~mm} /$ year (Ncube, 2007) with an estimated $7085 \%$ of rainfall lost through evaporation, surface runoff and deep percolation. Rain falls as short duration, high intensity convective storms that can give rise to severe soil erosion and surface crusting (Nonner, 1997; Graef and Stahr, 2000). The raindrop impact on the soil surface promotes crusting which retards infiltration of rainwater into the soil (Mellis et al., 1996; Graef and Stahr, 2000). This in turn increases surface runoff and hence water loss from the field (Twomlow and Bruneau, 2000). Coupled with a high atmospheric evaporative demand of about 1.5-10 times the total annual rainfall (Barron, 2004), soil moisture is therefore one of the major limiting factors to semi-arid crop production.

Conservation tillage practices can potentially address the soil and water management constraints faced by smallholder farmers in semi-arid areas. In view of this, several studies have been conducted 
on water and soil management in semi-arid areas (Twomlow and Dhliwayo, 1999; Twomlow and Bruneau, 2000; Nyagumbo, 2002). Hand and animal powered techniques for soil and water management are being promoted in the semi-arid smallholder farming sector of southern Zimbabwe (Mupangwa et al., 2006). Conservation tillage techniques such as planting basins and tine ripping have brought a ray of hope to soil water management in semi-arid southern Zimbabwe. These tillage techniques can potentially address both soil water availability to crops and the soil physico-chemical limitations facing smallholder farmers. This study was designed to quantify (i) surface runoff losses from fields under each of the four tillage treatments and (ii) soil water contributions of planting basins, tine ripping, single and double conventional spring ploughing. Measurements of soil water and surface runoff were made on bare plots from December 2006 following maize crop failure due to drought.

\section{Materials and methods}

\subsection{Site descriptions}

The experiments were established and conducted in Insiza and Gwanda districts of Matebeleland South province, which forms part of the Mzingwane catchment in southern Zimbabwe. The climate of Insiza and Gwanda is characterised by a unimodal rainy season from November to March and a dry winter season from May to September. Rainfall is low (250-550 mm/year) and variable, decreasing from the northeast to the southwest with a mean annual rainfall of $480 \mathrm{~mm} /$ year. The major soils are coarsegrained sands to loamy sands and are classified as $5 \mathrm{G}$ according to the Zimbabwe Soil Classification system. Vegetation consists of Colophospermum mopane as the dominant tree species with scattered associated tree species of Commiphora spp. Combretum apiculatum and Adonsonia digitata. The relief varies between undulating in Insiza district to flat in Gwanda district. The farming system of both districts consists of a combination of crop and livestock enterprises. The major cereals grown are maize, sorghum and pearl millet while the livestock enterprise comprises cattle, goats, donkeys and poultry. Legumes such as groundnut, bambaranut and cowpea are also grown as sole crops or intercrops with cereals.

\subsection{Experimental set up}

The experiment was established at four farms, two in Insiza district (Upper Mzingwane subcatchment) and two in Gwanda district (Lower Mzingwane subcatchment). Four tillage treatments namely planting basins, tine ripping (using Zimplow ripper), single and double ploughing were compared at each farm. Planting basins and tine ripping are technologies that are currently being promoted in smallholder farming areas of southern Zimbabwe. Double ploughing has been promoted by the Department of Research and Extension (AREX) as a way for conserving soil moisture after farmers have finished harvesting. Single ploughing is the current normal practice by smallholder farmers in Matebeleland South province. Digging of planting basins, tine ripping and the first ploughing of double ploughing treatment were done in October 2006. The second ploughing of the double ploughing treatment was carried out after the first effective rains when farmers were planting (last week of November 2006). Single conventional ploughing was done after the first effective planting rains.

Four plots measuring $30 \mathrm{~m} \times 10 \mathrm{~m}$ each were pegged out at each farm. The recommended dimensions of each planting basin i.e. $0.15 \mathrm{~m}$ (length) $\times 0.15 \mathrm{~m}$ (width) $\times 0.15 \mathrm{~m}$ (depth) and spacing of $0.90 \mathrm{~m} \times 0.60 \mathrm{~m}$ (ICRISAT, 2006) were adopted in this study. Interrow spacing for the riplines used was $0.90 \mathrm{~m}$. Depth of ripping averaged $0.18 \mathrm{~m}$ across the four farms. Ploughing depth in both single and double ploughing treatments ranged between $0.15 \mathrm{~m}$ and $0.18 \mathrm{~m}$ across the four farms. Ripping and ploughing depths depended on the ability of each farmer's draught animals to pull the ripper or the plough during tillage operations. All host farmers used a span of four donkeys during the tillage operations in both districts.

Each of the $30 \mathrm{~m} \times 10 \mathrm{~m}$ plot was subdivided into three $10 \mathrm{~m} \times 10 \mathrm{~m}$ subplots and an access tube was sunk at the center of each subplot for soil water measurements. The depth of each access tube depended on the soil profile characteristics at each farm. However, the depth of tubes ranged between 0.60 and $0.80 \mathrm{~m}$ across the four farms. Under planting basins tillage treatment, access tubes were sunk between basins in a row. In the ripper tillage treatment access tubes were sunk along the rip furrow. In the single and double ploughing treatments access tubes were sunk along the maize planting rows.

Under each tillage treatment, one of the $10 \mathrm{~m} \times 10 \mathrm{~m}$ subplots was used for the determination of runoff losses. The borders of runoff plots were made from heat resistant polythene plastic. The polythene plastic prevented water flow from other parts of the field onto the runoff plot. At the down slope side of each runoff plot a triangular area (10 m wide and $1.7 \mathrm{~m}$ high) was covered in black plastic sheet to collect runoff water from plot. The apex of the triangle led the water into a polythene plastic pipe and discharged into a 2001 drum.

\subsection{Measurements}

Bulk density was measured up to $0.60 \mathrm{~m}$ depth using the procedure outlined by Anderson and Ingram (1993). Soil texture was determined at each site using the hydrometer method (Anderson and Ingram, 1993). At each farm daily rainfall was measured from October 2006 to April 2007 using a standard rain gauge. Runoff water collected in each drum was measured after every runoff-generating rainfall event. A staff gauge graduated to the nearest centimetre was used to measure the depth of water in each drum. The drums were emptied after each rainfall event. Soil water was measured fortnightly using a capacitance probe to a depth of $0.60 \mathrm{~m}$.

\subsection{Statistical analysis}

The runoff and soil water content data were analyzed using the method of residual maximum likelihood (REML) included in Genstat 6.1 statistical package. The REML method accounts for more than one source of variation and makes it possible to analyze data from unbalanced designs. With runoff monitoring the unbalanced nature of the design arose from differences in the number of runoff generating storms recorded at the different experimental sites. Unbalanced design was applied in the analysis of soil water data because depths from which soil water could be measured varied across the four farms. Treatment means were separated using standard error of difference between means (SED). Probability levels of 0.001, 0.01 and 0.05 were used to determine level of significant difference between treatment means. The following models were used;

Runoff $(\mathrm{Q})=$ Constant + Tillage + Residual

Soil water $(\mathrm{SW})=$ Constant + Tillage + Depth + Date + Tillage Depth + Tillage.Date + Depth.Date + Tillage.Depth.Date + Residual

\section{Results}

\subsection{Site characteristics}

The soil profiles indicated a slight decrease in bulk density with depth at all farms (Table 1 ). Soil texture ranged from sandy (Mpofu farm) to sandy loam (Nyathi farm) while organic carbon content decreased with depth except at Ncube farm in Gwanda. (See Fig. 1) 
Table 1

Physical and chemical properties of soils at the experimental sites used in Gwanda and Insiza districts during 2006/07 farming season

\begin{tabular}{|c|c|c|c|c|c|c|c|}
\hline \multirow[t]{2}{*}{ Farm } & \multirow[t]{2}{*}{$\operatorname{Depth}(\mathrm{cm})$} & \multirow[t]{2}{*}{ Bulk density $\left(\mathrm{g} / \mathrm{cm}^{3}\right)$} & \multicolumn{3}{|c|}{ Soil texture (\%) } & \multirow[t]{2}{*}{ Soil $\mathrm{pH}$ ( $1: 1$ water $)$} & \multirow[t]{2}{*}{ Soil O.C.(\%) } \\
\hline & & & Clay & Silt & Sand & & \\
\hline \multirow[t]{4}{*}{ Sibanda } & $0-15$ & 1.51 & 4 & 6 & 90 & 4.8 & 0.48 \\
\hline & $15-30$ & 1.49 & 5 & 6 & 89 & 4.4 & 0.49 \\
\hline & $30-45$ & 1.46 & 5 & 8 & 87 & 4.4 & 0.44 \\
\hline & $45-60$ & 1.47 & 5 & 3 & 92 & 4.0 & 0.41 \\
\hline \multirow[t]{4}{*}{ Mpofu } & $0-15$ & 1.46 & 3 & 6 & 91 & 5.3 & 0.58 \\
\hline & $15-30$ & 1.45 & 4 & 5 & 91 & 5.4 & 0.41 \\
\hline & $30-45$ & 1.43 & 6 & 5 & 89 & 5.4 & 0.46 \\
\hline & $45-60$ & 1.46 & 7 & 4 & 89 & 5.5 & 0.42 \\
\hline \multirow[t]{4}{*}{ Nyathi } & $0-15$ & 1.50 & 6 & 13 & 81 & 6.3 & 0.71 \\
\hline & $15-30$ & 1.51 & 10 & 9 & 81 & 6.5 & 0.68 \\
\hline & $30-45$ & 1.48 & 16 & 8 & 76 & 6.7 & 0.66 \\
\hline & $45-60$ & 1.48 & 17 & 10 & 73 & 6.9 & 0.59 \\
\hline \multirow[t]{4}{*}{ Ncube } & $0-15$ & 1.50 & 10 & 4 & 86 & 5.2 & 0.26 \\
\hline & $15-30$ & 1.47 & 11 & 3 & 86 & 4.9 & 0.38 \\
\hline & $30-45$ & 1.49 & 16 & 6 & 78 & 5.3 & 0.37 \\
\hline & $45-60$ & 1.48 & 18 & 6 & 76 & 4.5 & 0.34 \\
\hline
\end{tabular}

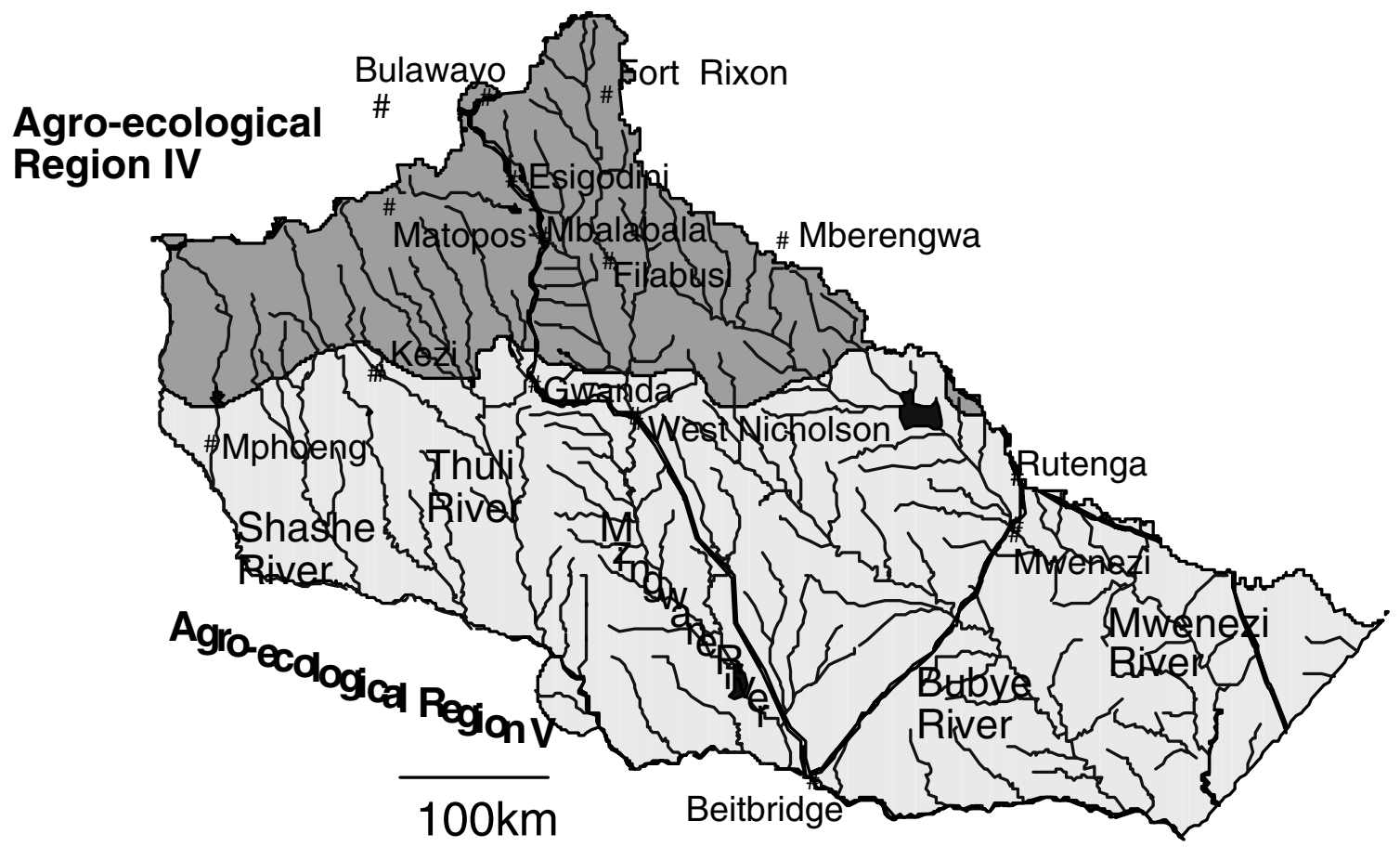

Fig. 1. Location of study sites in the Mzingwane river catchment in southern Zimbabwe.

\subsection{Rainfall patterns at the four farms}

The cumulative rainfall observed at each farm between 1 October 2006 and 30 April 2007 is shown in Fig. 2. All farms except one received more than $100 \mathrm{~mm}$ rainfall over the 28 December 2006 (day 89) to 1 January 2007 (day 93) period. The total rainfall received over that 5-day period ranged from $47 \mathrm{~mm}$ to $150 \mathrm{~mm}$. In Insiza district the next rainfall event after 1 January 2007 occurred six weeks later with Mpofu and Nyathi farms recording $24 \mathrm{~mm}$ and $28 \mathrm{~mm}$ respectively. In Gwanda district the next rainfall event after 1 January 2007 (day 93) occurred eight weeks later with Sibanda and Ncube farms recording $26 \mathrm{~mm}$ and $49 \mathrm{~mm}$ respectively. Rainfall remained erratic up to the end of the cropping period.

\subsection{Daily runoff from experimental plots}

Six runoff-generating rainstorms were recorded at each farm in Insiza district. Only three runoff-generating rainstorms were recorded at the Gwanda farms. Rainfall amounts recorded at the four farms were different. This resulted in significant $(p=0.01)$ differences in the volumes of runoff observed across the 4 farms irregardless of the tillage treatment. Planting basins tillage treatment gave the lowest $(p=0.003)$ daily runoff losses across all farms (Fig. 3). At the sandy soil site, Mpofu farm, single and double spring conventional ploughing gave similar water losses from the plots. Similar results between these two tillage treatments were also observed at Ncube farm in Gwanda district. The highest 


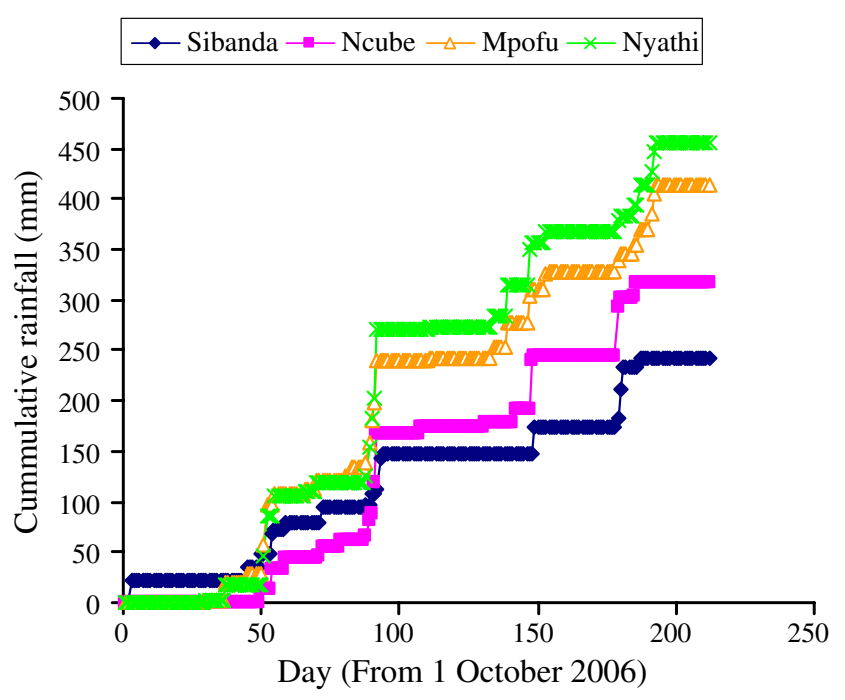

Fig. 2. Cumulative rainfall recorded at Sibanda, Ncube, Mpofu and Nyathi farms in Insiza and Gwanda districts between 1 October 2006 and 30 April 2007.

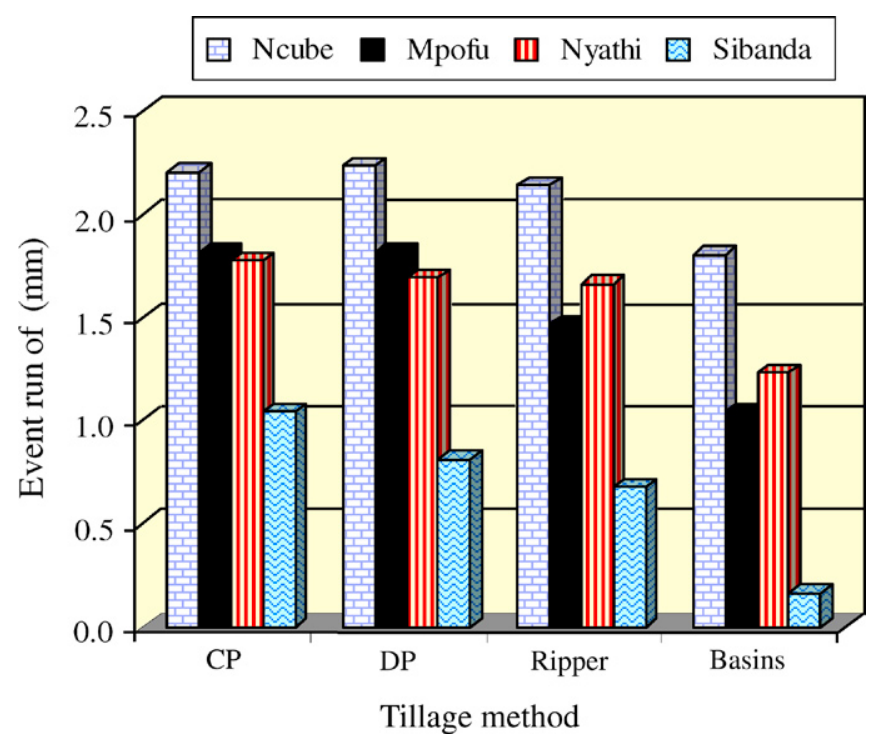

Fig. 3. Event runoff measured under each tillage treatment at Mpofu, Nyathi, Ncube and Sibanda farms in Insiza and Gwanda districts between 30 December 2006 and 30 April 2007.

runoff water losses from planting basins and ripper treatments were observed at Ncube farm. On average runoff water losses ranging from 0.2 to $2 \mathrm{~mm} /$ storm were recorded from planting basin treatment across the 4 farms. Runoff water losses ranged from $1-2.2 \mathrm{~mm} /$ storm for single conventional ploughing, $0.8-2.2 \mathrm{~mm} /$ storm for double ploughing and $0.7-2.2 \mathrm{~mm} /$ storm for ripper tillage treatments.

The relationships between runoff generated under each rainfall event and rainfall recorded at the Insiza farms are shown in Fig. 4 and Fig. 5. The relationship between daily runoff and rainfall under each tillage treatment was week at the two farms (Table 2). Daily runoff was $7 \%$ of rainfall received at the sandy soil Mpofu farm under single and double ploughing. A similar trend between runoff and rainfall was observed at Nyathi farm under single and double spring ploughing treatments. Planting basins treatment had an average of $4 \%$ of the recorded rainfall as runoff across the two farms.

\begin{tabular}{|c|c|}
\hline - $\mathrm{CP}$ & $\Delta \quad$ Ripper \\
\hline $\begin{array}{c}\times \quad \text { Basins } \\
\ldots \text { - Linear }(\mathrm{DP})\end{array}$ & 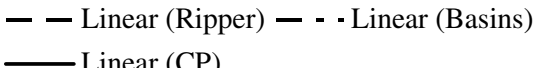 \\
\hline
\end{tabular}

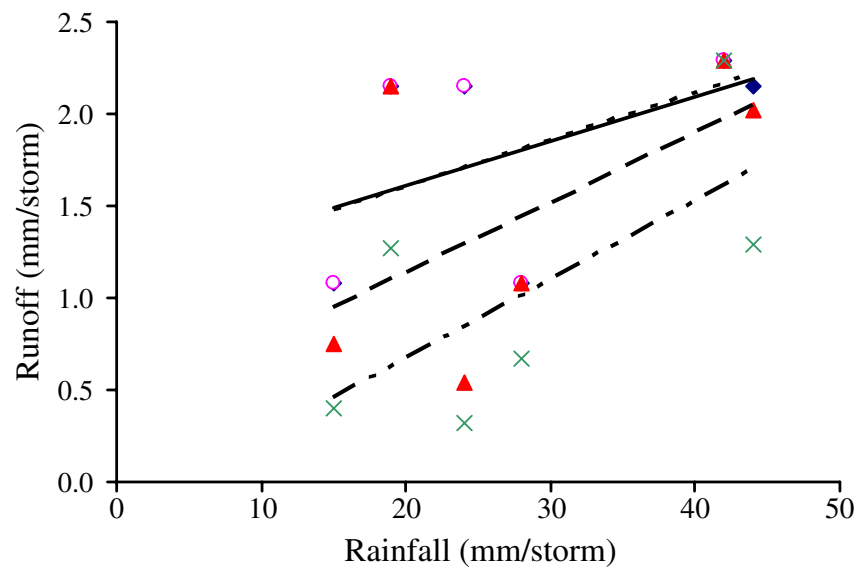

Fig. 4. Relationship between daily rainfall and runoff at Mpofu farm (Insiza) between 30 December 2006 and 30 April 2007.

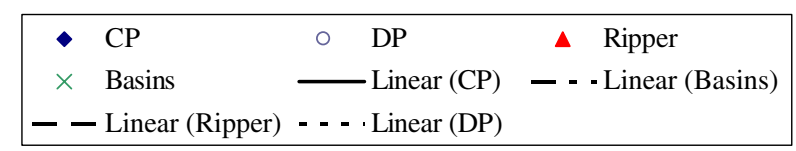

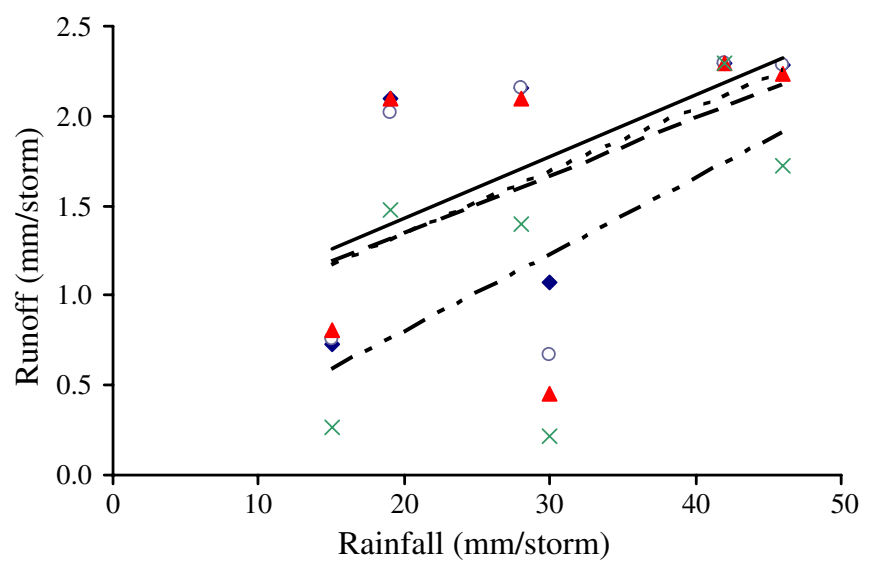

Fig. 5. Relationship between daily rainfall and runoff at Nyathi farm (Insiza) between 30 December 2006 and 30 April 2007.

\subsection{Soil water content}

Despite the below average rainfall observed across the study sites, soil water regimes did respond to each rainfall event. At Mpofu and Nyathi farms with sandy and sandy loam soils, planting basins treatment consistently gave the highest $(p<0.001)$ soil water content throughout the four-month study period (Fig. 6 and Fig. 7). In Gwanda at Sibanda farm (loamy sand) planting basins and double ploughing (DP) treatments had similar soil water content in April 2007 (Fig. 8). At Mpofu farm soil water content under the single conventional ploughing $(\mathrm{CP})$ treatment was marginally lower than planting basins treatment but higher than ripper and double ploughing treatments in January. Single conventional ploughing treatment retained the lowest soil water content from February to April 2007 at Nyathi, Sibanda and Ncube farms. At Ncube farm the highest soil water content was observed under the ripper tillage treatment (Fig. 9). There was noticeable crusting in 


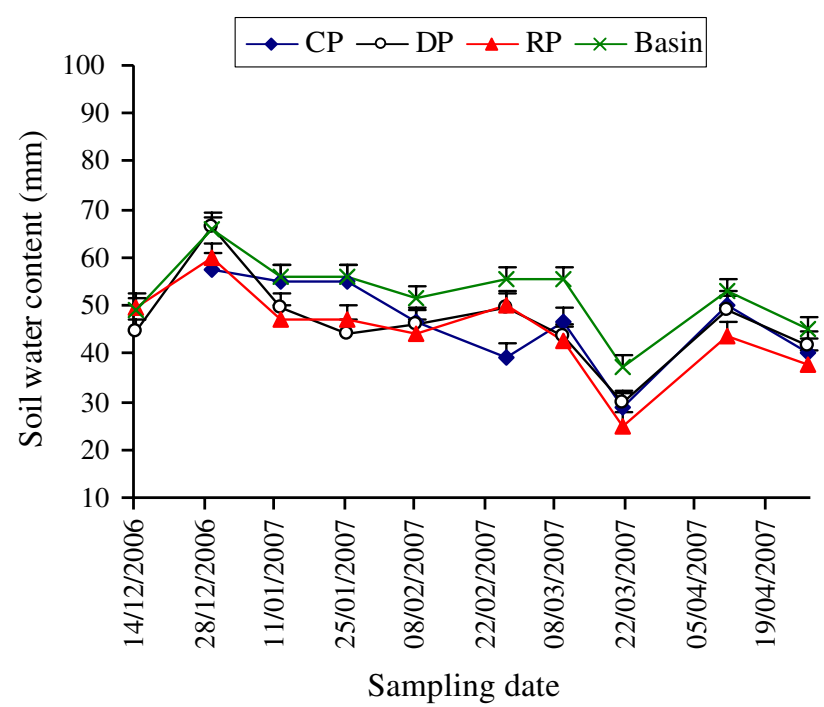

Fig. 6. Soil water variation in the $0-0.6 \mathrm{~m}$ soil layer under 4 tillage treatments at Mpofu farm (Insiza district) between 14 December 2006 and 30 April 2007. Bars indicate standard error.

Table 2

Relationships between runoff and rainfall at the two experimental sites in Insiza district

\begin{tabular}{lllll}
\hline Farmer & Tillage & Regression equation & $R^{2}$ value & $\begin{array}{l}\text { Runoff: } \\
\text { rainfall ratio }\end{array}$ \\
\hline Mpofu & CP & $Q=0.022 P+1.21$ & 0.24 & 0.071 \\
& DP & $Q=0.025 P+1.09$ & 0.28 & 0.069 \\
& Ripper & $Q=0.038 P+0.38$ & 0.35 & 0.054 \\
& Basins & $Q=0.043 P-0.19$ & 0.48 & 0.036 \\
Nyathi & CP & $Q=0.034 P+0.74$ & 0.37 & 0.063 \\
& DP & $Q=0.035 P+0.65$ & 0.31 & 0.060 \\
& Ripper & $Q=0.032 P+0.69$ & 0.24 & 0.059 \\
& Basins & $Q=0.055 P-0.31$ & 0.53 & 0.040 \\
\hline
\end{tabular}

$Q=$ runoff, $P=$ precipitation.

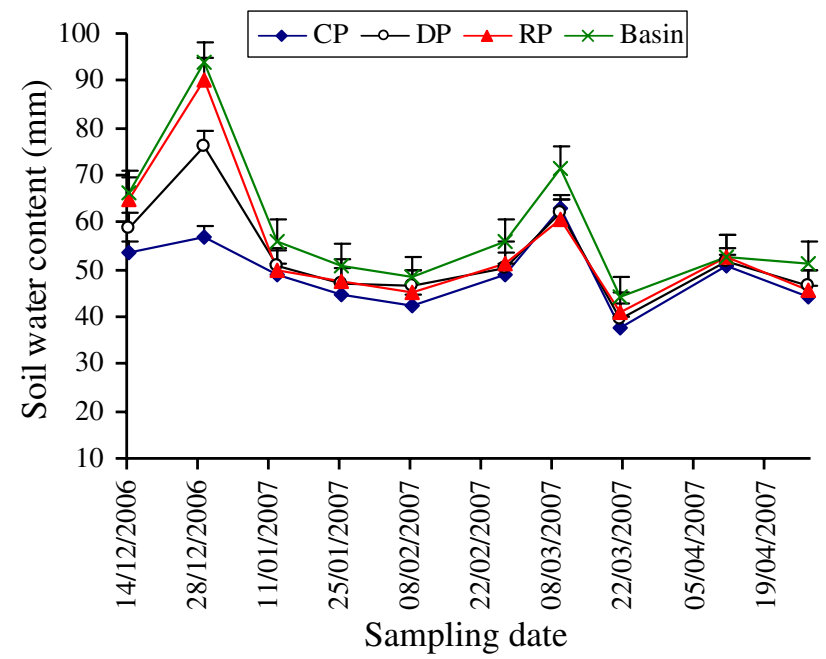

Fig. 7. Soil water variation in the $0-0.6 \mathrm{~m}$ soil layer under 4 tillage treatments at Nyathi farm (Insiza district) between 14 December 2006 and 30 April 2007. Bars indicate standard error.

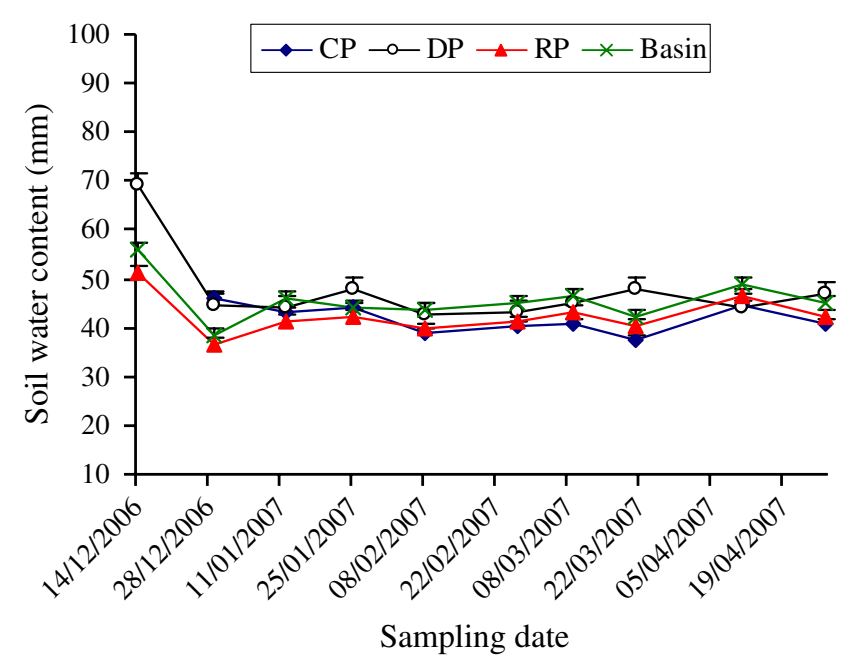

Fig. 8. Soil water variation in the $0-0.6 \mathrm{~m}$ soil layer under 4 tillage treatments at Sibanda farm (Gwanda district) between 14 December 2006 and 30 April 2007. Bars indicate standard error.

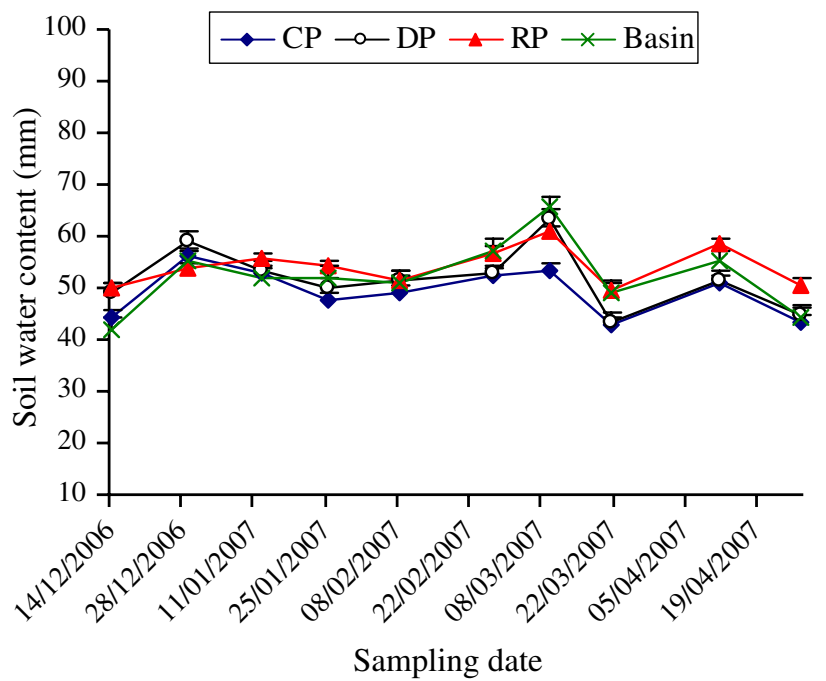

Fig. 9. Soil water variation in the $0-0.6 \mathrm{~m}$ soil layer under 4 tillage treatments at Ncube farm (Gwanda district) between 14 December 2006 and 30 April 2007. Bars indicate standard error.

all experimental plots at Ncube and Nyathi farms especially after the heavy rains that were received at the beginning of January and end of March.

\section{Discussion}

The rainfall pattern was very erratic throughout the season and long dry spells were observed across all experimental sites (Fig. 2). The dry periods are shown by horizontal sections of each line for the four farms (Fig. 2). The long dry spells observed during the 2006/07 farming season are a common feature especially during drought years in semi-arid areas. The rainstorms of 70 and $50 \mathrm{~mm}$ recorded at Nyathi and Ncube farms at the turn of the year (2007) resulted in noticeable soil crusting at some experimental plots. Heavy rainstorms of 49 and $50 \mathrm{~mm}$ were further observed at Ncube farm in February and March.

The loosening of soil during ploughing coupled with surface crusting could have promoted high runoff losses measured under 
single and double conventional tillage treatments. The heavy rainfall events observed could have promoted soil surface sealing and crusting, and reduced infiltration (Al-Qinna and Abu-Awwad, 2001; Bouman, 2007) thereby increasing surface runoff from ploughing and ripping tillage treatments. As the season progressed surface roughness decreased in all four tillage treatments but the decline was least in planting basin experimental plots.

The four tillage treatments harvested different quantities of rainwater with planting basins having consistently higher soil water content at three of the four farms. The tillage treatments affected soil surface microtopography to varying degrees. The grid of $0.9 \mathrm{~m} \times 0.6 \mathrm{~m}$ spaced planting basins created a higher surface roughness compared to the other tillage treatments resulting in superior rainwater harvesting and better promotion of infiltration. As observed by Guzha (2004) the higher the surface roughness the greater the potential for depression water storage. As the season progressed the planting basin structure did not collapse completely as the basins were filled with soil. This allowed continued harvesting of rainwater up to the last rainfall event of the season in April. Results from a study by Guzha (2004) revealed that surface roughness decreases exponentially with increase in cumulative rainfall.

Although the single conventional ploughing treatment started off with higher soil water content at some farms in January, the treatment ended up having the least quantity of soil water by the end of the season. This initial high soil water content under ploughing can be attributed to increased porosity of the soil following loosening during tillage operation. Initially ploughing reduces bulk density, increases porosity and infiltration capacity of the surface soil layer (Das and Chopra, 1988; Sasal et al., 2006; van der Meer, 2000). However, as the season progresses compaction begins in the surface soil layer resulting in a reduction in soil porosity. Consequently infiltration capacity of the surface soil layer decreases as a result of reduced pore space (Shinde et al., 1982). Ploughing may promote better soil water storage during rainy periods but can also accelerate soil evaporation during dry periods (Debaeke and Aboudrare, 2004). Furrows created by tine ripping were easily filled with soil as the season progressed and this resulted in reduced rainwater harvesting ability of the tillage treatment.

\section{Conclusion}

Results from this study have shown that planting basin tillage method gives a better control of water losses from the farmers' fields. Despite the below average rainfall received during the study period planting basin tillage method has a greater potential for capturing rainwater and promoting infiltration than ripper, double and single conventional ploughing techniques.

\section{Acknowledgement}

This paper is a contribution to WaterNet Challenge Program Project 17 "Integrated Water Resource Management for Improved Rural Livelihoods: Managing risk, mitigating drought and improving water productivity in the water scarce Limpopo Basin". The cooperation of farmers and the Department of Agricultural
Research and Extension Services in the Ministry of Agriculture and Rural Development (Matabeleland South Province) is gratefully acknowledged.

\section{References}

Al-Qinna, M.I., Abu-Awwad, A.M., 2001. Wetting patterns under trickle source in Arid and semi-arid soils with surface crust. Journal of Agriculture. Engineering Research 80 (3), 301-305.

Anderson, J.M., Ingram, J.S.I., 1993. Tropical soil biology and fertility. Second ed, In: A Handbook of Methods, Springer, Wallingford, UK, pp. 221.

Barron, J., 2004. Dry spell mitigation to upgrade semi-arid rainfed agriculture: Water harvesting and soil nutrient management for smallholder maize cultivation in Machakos, Kenya. Ph.D. thesis in Natural Resources Management. Department of Systems Ecology, Stockholm University, Sweden.

Bouman, A.B.M., 2007. A conceptual framework for the improvement of crop water productivity at different spatial scales. Agriculture Systems 93, 43-60.

Das, D.K., Chopra, U.K., 1988. Soil water movement, balance and its use by crops as influenced by soil physical conditions. In: Somani, L.L. (Ed.), Soil Physical Conditions and Crop Growth.In: Monograph, Geo-Environ Academia and Divyajyoti Prakashan, Shatri Nagar, India, pp. 231-254.

Debaeke, P., Aboudrare, A., 2004. Adaptation of crop management to water-limited environments. European Journal Agronomy 21, 433-446.

Graef, F., Stahr, K., 2000. Incidence of soil surface crust types in semi-arid Niger. Soil and Tillage Research 55, 213-218.

Guzha, A.C., 2004. Effect of tillage on soil microrelief, surface depression storage and soil water storage. Soil and Tillage Research 76, 105-114.

Mellis, D.A., Bruneau, P.M.C., Twomlow, S.J., Morgan, R.P.C., 1996. Field assessment of crusting on tilled sandy clay loam. Soil Use and Management 12, 72-75.

Mupangwa, W., Love, D., Twomlow, S.J., 2006. Soil-water conservation and rainwater harvesting strategies in the semi-arid Mzingwane Catchment, Limpopo Basin, Zimbabwe. Physics and Chemistry of the Earth 31, 893900 .

Ncube, B. 2007. Understanding cropping systems in semi-arid environments of Zimbabwe: options for soil fertility management. Ph.D. Thesis, Wageningen University, Wangeningen, The Netherlands, pp. 155.

Nonner, J., 1997. Principles of Hydrogeology, In: IHE Lecture Note, IHE, Delft, The Netherlands.

Nyagumbo, I., 2002. The effect of three tillage systems on seasonal water budgets and drainage of two Zimbabwean soils under maize. Ph.D. thesis (unpublished), University of Zimbabwe, pp. 251.

Nyamangara, J., Mpofu, S.E., 1996. Soil pH and lime requirement for high potential communal areas of Zimbabwe. Journal of Applied Science in Southern Africa 2, 77-81.

Rockstrom, J., Barron, J., Fox, P., 2002. Rainwater management for increased productivity among smallholder farmers in drought prone environments. Physics and Chemistry of the Earth. 27, 949-959.

Sasal, M.C., Andriulo, A.E., Taboada, M.A., 2006. Soil porosity characteristics and water movement under zero tillage in silty soils in Argentinean Pampas. Soil and Tillage Research 87, 9-18.

Shinde, S.S., Magar, S.S., Kale, S.P., 1982. Effect of soil physical conditions and initial soil moisture content on infiltration into black soil. Journal of Indian Social Soil Science 30, 441-446.

Tsimba, R., Hussein, J., Ndlovu, L.R., 1999. Relationships between depth of tillage and soil physical characteristics of sites farmed by smallholders in Mutoko and Chinyika in Zimbabwe. On: <http://www.fao.org/ag/ags/agse/3ero/namibia1/ c11.htm>. Visited on 2 July 2007.

Twomlow, S.J., Dhliwayo, H., 1999. Semi-arid maize yield responses to conservation tillage and weeding. Brighton Crop Protection Conference - Weeds, November 1999. Farnham, Surrey, UK: BCPC.

Twomlow, S.J., Bruneau, P.M.C., 2000. The influence of tillage on semi-arid soilwater regimes in Zimbabwe. Geoderma 95, 33-51.

Twomlow, S.J., Steyn, J.T., du Preez, C.C., 2006. Dryland farming in southern Africa. Dryland Agriculture., Second ed. Agronomy Monograph No. 23. American Society of Agronomy, Madison, Wisconsin, pp. 769-836. (Chapter 19).

Van der Meer, F.W., 2000. Modelling tropical soil water regimes in semi-arid environments. Ph.D. thesis (unpublished), Loughborough University. pp. 270.

Whitlow, R., 1988. Potential versus actual erosion in Zimbabwe. Applied Geography $8(2), 87-100$. 